\title{
English For Specific Purposes: Need Analysis
}

${ }^{1}$ Like Raskova Octaberlina, ${ }^{2}$ Muthmainnah (2021).

${ }^{1}$ Universitas Islam Negeri Maulana Malik Ibrahim, Malang, Indonesia

${ }^{2}$ Universitas Al Asyariah Mandar, Indonesia

\section{A R T I C LE I N F O}

Keywords

ESP (English for Specific

Purposes), and Needs Analysis

\begin{abstract}
Considered a method in the field of data collection (Nunan, 1988), need analysis can be a crucial advantage for English teachers for special purposes (ESPs) in recognizing learner's primary needs and skills. Students addressed the need analysis priority. Although the needs of learning are taken into account by Hutchin and Waters (1987) to learn, Benesch (2011: 1972) perceives that needs are strictly linked to the demands of the target situation. Other researchers such as Taillefer, (2007) and Cowling, (2007) show that the effectiveness of ESP teaching and learning relies heavily on the study of needs. It is thus clear that needs analysis will enable learners to adjust to the new method of learning if their teachers understand their needs (Carkin, 2005; Chamot, 2007). A strong benefit of the requirement analysis is that the analysis of requirements recognizes the shortcomings and strengths of the credentials which they may employ in future business or academic environments. This study is then added to the bulk of ESP requires analysis studies. It can be regarded as a proactive and analytical effort to assist Saudi Arabia ESP teachers in determining the most efficient and suitable teaching practices for their students.
\end{abstract}

\section{INTRODUCTION}

In reality, according to Katz-Haas, it's about who you are, how you identify your goals and tasks, the knowledge you have, what functions you want and need from your system, which information you want and how you need it, and how you understand what your system is. Job. Work. Work. The user-centered design was also related to defining the work performance requirements needed, evaluating the skills and establishing goals of potential trainees.

The first step in a user-centric design process is user requires understanding. Simply put, while needs analysis focuses on the elements to be present in the system, needs analyzes concentrate on the requirements relevant to the user and/or user community's priorities, expectations and needs and include them in the process of analysis of system needs. User satisfaction is the key focus of needs research.

Because the analysis of needs is focussed on human needs, it can be extended to all realms such as vehicles, consumer goods or services as banking, and can not only fix software requirements. While it is not a tool for business growth, it can be used to help in the development of business cases.

We can identify customer needs in three ways:

$\checkmark$ Client request,

$\checkmark$ Modification of existing designs,

$\checkmark \quad$ New product generation

English is very important because of its international language status in different fields, especially education. English is an international language. In Indonesia, this reality motivated education to make language mandatory. It has been taught both formally and informally at different levels of education. This language is formally learned through the execution of curricular courses at different levels of education, consisting of primary, secondary and universities. The English learned in the formal education is dependent on the level of training and the English learned at the primary, junior high and high school levels is generally known as General English, while the English is studied at the level of education. English is often learned in an informal manner by language schools. Universities are called ESP because they are taught in a field of science (English for Particular Purposes). ESP itself seeks to provide students with their major's basic English. Students should be equipped with English language skills to learn English. 
It is very useful to students to explore the fields of science they are learning in order to use english, particularly ESP. Students are able to understand the contenus of reference books, the internet, scientific journals or other information sources that use English, with their outstanding English skills. Moreover, students must practice their English skills for their future professional jobs, as the ability to use English will be of great use when they are vying for a job. Given the importance of English for students, English subjects/research programs that are suitable for their needs must be planned. Teachers must be completely aware of the consistency and suitability of the material formulation. In terms of achieving their goals, content in the English module will not be successful if they are not formulated in accordance with the requirements of students. One of the topics regarded as challenging since many students do not have clear fundamentals of English is the English subject for nonEnglish students. This non-English junior subjection is a challenge for the teachers of English. Besides the correct approach, a module that is high quality and in line with the needs of the students should be used to help the teaching.

The need analysis is a tool which cannot be disconnected from the creation of materials and curricula for language learning, in particular ESP. Basturkmen (2010: 17) reaffirms this, saying the study of needs is to define the language and capacity that ESP-based learning materials are employed to assess and choose. Students and the learning process may also be measured at the end of the training cycle by evaluating them. The method used for gathering information on the students needs of students is referred to as needs analysis by Richard (as quoted in Puspitasari, 2013: 23). The method of collecting data on the needs of students must be analysed, says Nunan (in Sukarni, 2016: 13). The disparity between goals and learning needs must first be established before the study is carried out. Hutchinson and Waters also divide needs into target needs (as quoted in Nuryanto in 2018: 27) (what students can convey in target situations) and learning needs (what students need to learn). 1) Needs: Which language aspects students need to accomplish goals effectively 2) Weaknesses: What students did not master 3) Wants: What research students want to learn 2) What students want to learn

Adult learners' language is usually divided into two main categories: General Objective English (EGP) and Particular Objective English (ESP) based on the specific nature of the targets to be accomplished. (Basturkmen, 2010: 17), Chan, Yan, and Sun. Hutchinson and Waters (2016:6) stress that ESP and EGP do not vary according to student needs but because they are conscious of student needs. The value of needs analysis and method is understood by all interested participants, learners, instructors, stakeholders and potential users. The creation of instructional materials is an essential key that distinguishes ESP or EGP learning activities, and is aware of how this need analytics are carried out and how to respond to the overall learning process including the application of the effects of the analysis of needs. 2015) notes that three ESP key features distinguish it from General English or Foreign Language (EFL) or Mother language English (EMT). The features are:

1) ESP is goal-oriented learning. In this context, students learn English not because they want to know a language as the language and culture it contains, but they learn ESP because it has certain goals in the academic and professional fields.

2) The ESP substance is designed and developed based on the concept of needs analysis. The concept of needs analysis aims to specialize, connect, and unify what students need in both the academic and professional fields.

3) ESP is more specifically aimed at adult learners than children or adolescents. This is logical because ESP is generally taught for students at intermediate and higher academic levels, for professionals or for workers in the workplace.

\section{What is a Needs Analysis?}

An overview of needs describes shortcomings or problems and suggests causes and solutions. It can be called to define the differences between what is to happen and what is to happen and to take account of the causes of these gaps. In this way, the search is systematic for the shortcomings between current and desired work performance as presented in the following steps to avoid desiring job performance: 


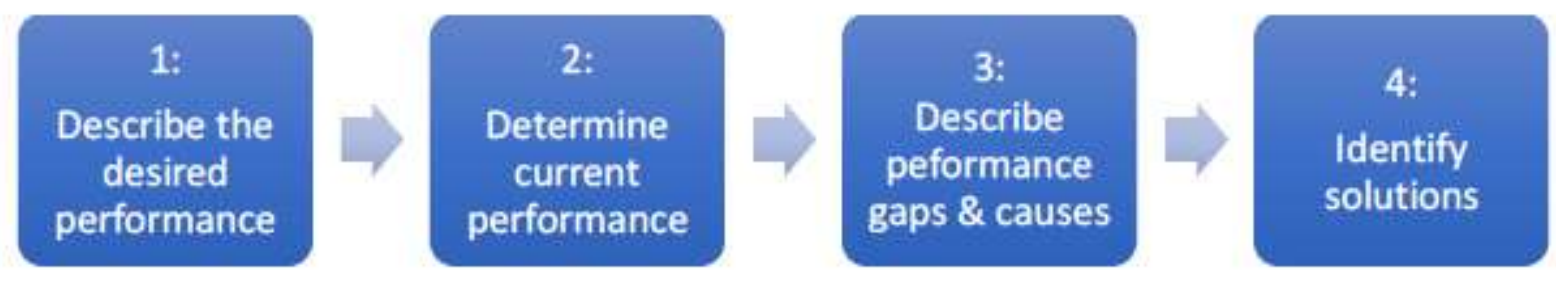

1. What are the performance expectations (desired state)?

2. What is the current state of performance?

3. What are the gaps to peformance (Needs) and causes?

4. What are the solutions to bridge the gap?

\section{When is a Needs Analysis used?}

Berkeley Lab Training performs a needs analysis in the following situations:

- When there is a request for a new training (or change to current training)

- Whenever new requirements are issued

- When it has been identified that job performance is below expectations (identified through work observation, self-assessments, audits, etc)

Since we know ESP is a study model focused on the question: 'Why do those students have to learn English? '(Why do these students have to learn English?') But this question needs to be asked of students with a different subject, general or ESP. As this is the learning model that is used specifically in accordance with students' needs in their own fields.

They need more analytical practice for general English students. This is a quicker assumption. But this presumption is very weak because the need for some generalized branch of English is probably often decided. The need is decided by the disparity between ESP and general English, but knowledge is the engine. E.g., students, supporters, or teachers, who see why they speak English, will want to find anything they need to improve their English skills.

In general English, ESP has a significant role to play and is more than a casual approach. However, the ESP solution still needs to take account of the student's objective condition, the need to speak English. This distinguishes between ESP students and English in general. Munby defined a target called the Communication Needs Processor, a set of questions on key communication variables, to evaluate the situation of target student need (topics, participants, tools, etc.). As this CNP develops, the ESP seems to have taken a long time to grow. Machines have been provided to classify the needs of learning groups: they must be able to be managed by all educational designers. The languages of the target situation are also presented in this CNP.

Before carrying out the analysis, we must know in advance to distinguish between target needs (what is learned in the target situation) and learning needs (what is learned in learning).

1) What is the definition of Target Needs (Target Needs)?

Target needs is a general term, which in practice hides a number of important differences. This target needs looks more at the target situation terms of Necessities (needs), Lacks (shortages), and Wants (wants):

$\checkmark$ Necessities

We can define 'necessities' as a type of need that is determined by the demands of the target situation, that is, what the learner must know in order to function effectively as targeted. For example: a businessman, according to the needs of the target situation he must understand business letters, to be able to communicate effectively during sales conferences, and to get information needs from sales catalogs etc. He must also understand the linguistic features - suspended, functional, structural, lexical that are commonly used in the situation.

$\checkmark$ Lacks (Weakness)

This analysis of student shortages was carried out to determine the types of needs needed by students.

$\checkmark \quad$ Wants (Desires)

So far, we only meet the needs of students only from their objective needs, where students play a 
passive role. In fact, students have a view of what their needs are. As Richterich (1984 p.29) says that the need does not exist in one's independence. The need is a description of their needs based on data relating to themselves and their environment.

2) Target situation

This target situation analysis is needed for material from asking questions about the target situation and attitudes towards the situation of all participants in the learning process.

Analysis Framework Target situation:

\# Why is English needed?

- To learn

- To work

- For training

* How will English be used?

- Medium: speaking, writing, reading, etc.

- Channel: telephone, face to face, etc.

* What areas will be discussed?

- Subjects: medicine, biology, architecture, mechanical engineering, etc.

- Level: Bachelor, Junior high school, technical expert, etc.

* Who will students use in language?

- Native or non-native speaker;

- Level of knowledge of receivers: experts, lay people, students;

* Where will the language be spoken?

- Physical setting: offices, hotels, workshops, libraries, faculty buildings;

- Human Context: meetings, demonstrations, telephone;

When will the language be used?

- Simultaneously with ESP learning or later in life.

- Often, rarely, on a small scale, on a large scale

3) Learning Needs (Learning Needs)

Analysis of what people do reveals nothing about what they have learnt. This is why ESP focuses not just on understanding or doing but also on what is to be learned in the learning of languages. In order to find the lessons required for the student, the learning conditions must first be understood as a task that is enjoyable, satisfactory, manageable, generative, etc.

4) Analyzing Learning Needs (Analysis of Learning Needs)

To analyze the learning needs of students, we can make an outline first.

Learning Needs Analysis Framework:

\# Why do students take subjects?

- Obligation or choice;

- Status, finances, involved promotions, etc.

\# How do students learn?

- From the background of the lesson;

- From the concept of teaching and learning, etc.

* What sources are available?

- Total ability and professional teachers;

- Teachers' attitude towards ESP, etc.

\# Who are the students?

- Age, gender, nationality;

- What do they know about English, etc.

* Where will ESP take place?

- In a pleasant, flat, noisy, cold, etc.

* When will ESP take place?

- Every day / once a week;

- Full time / part time, etc. 
ESP refers to any English language lessons used during academic or professional studies or in the teaching of English for a particular reason to non-English speakers learning English. The expert is the product of his research to establish such concepts but the same aim. In summary, we can conclude that ESP develops students' knowledge of their future issues, be it academic (when they choose their study career) or work, compared to English for general purposes. ESP thus includes the academic English language and the occupational English language. English has the definite objective of 'making students aware of the special communication needs of their future universities and professional communities, and we, university lecturers, strongly support this view, according to Kay Wester, the well-known ESP publishing professionals' sector.

\section{REFERENCES}

Nuryanto. (2018). Improving the Quality of Madrasah Ibtidaiyah: School-Based Management and Competence of Madrasah Teachers. Elementary Journal. Vol 4, 21-32.

Puspitasari, Indah. (2013). English For Computer Science: An Analysis of English Language Needs in Informatics Engineering Students. JurnalPro Bisnis. 6 (1), 21-37.

Sukarni, Sri. (2016). Analysis of the Needs of English for West Nusa Tenggara University Students. Journal of Scientific Development Media. 10 (1), 12-16

Balaei, Parisa \& Touran Ahour. (2018). Information Technology Students Language Requirement for their ESP Course. International Journal of Applied Linguistics \& English Literature. Vol 7, Issue 2, March 2018, 197-203.

Basturkmen, H. (2010). Developing a Course in English for a Specific Purpose.Hampshire: Palgrave Macmillan.

Ginanjar, Ega. (2015). English for Special Purposes (ESP Course Materials). Https://egaginanjar79.wordpress.com/2015/05/23/english-for-specific-purpose-materi-kuliah-esp/\#_ftn4. Retrieved 12 November 2018.

Hui, Guo. (2017). Analysis of Learning Needs of English for Special Purposes (ESP) in Higher Education. USChinese Foreign Language. Vol 15, No.1, January 2017, 1-6

George, Carole (2008-07-31). User-Centred Library Websites: Usability Evaluation Methods. Elsevier. ISBN 9781780631905.

Harris, C., 2002, Hyperinnovation: Multidimensional Enterprise in the Connected Economy, Palgrave Macmillan

Asrifan, A. (2009). Using songs in teaching English language for the young learners. ParePare: unpublished.

Puasa, K., Asrifan, A., \& Chen, Y. (2017). Classroom Talk in Bilingual Class Interaction. Research in Pedagogy, 7(1), 106-121.

Nadirah, N., Tahir, M. H., \& Asrifan, A. (2019). THE ABILITY TO TRANSLATE ENGLISH PHRASES INTO INDONESIAN AND THE DIFFICULTIES FACED BY THE ELEVENTH GRADE STUDENTS OF SMAN 1 PANCARIJANG. JOURNAL OF ADVANCED ENGLISH STUDIES, 2(1), 41-46.

Apdy, A. P. R., \& Asrifan, A. (2019, April). The Chinese mime game in teaching vocabulary on EFL classroom. In PROCEEDINGS OF THE 65th TEFLIN INTERNATIONAL CONFERENCE (Vol. 65, No. 01).

Taslim, T., Asrifan, A., Chen, Y., \& Nurdania, N. R. (2019). CORRELATION BETWEEN STUDENT'S VOCABULARY MASTERY AND SPEAKING SKILL. JOURNAL OF ADVANCED ENGLISH STUDIES, 2(2), 65-76.

Muthmainnah, M., Asrifan, A., Al Yakin, A., \& Sahabuddin, C. (2019, April). The use of dictogloss technique on ELT classroom: An experiment study of students listening comprehension. In PROCEEDINGS OF THE 65th TEFLIN INTERNATIONAL CONFERENCE (Vol. 65, No. 01).

Mutmainnah, M., Azis, S., Maulidya, U., \& Asrifan, A. (2017). Glory Style in Mandar Song Lyrics: A study of 
Mandar Tribe in South Sulawesi, Indonesia. JOURNAL OF ADVANCES IN LINGUISTICS, 8(1), 1286-1291.

Asrifan, A., Rinantanti, Y., Tang, S., \& Nadirah, N. (2019). THE 3-DIMENSION PICTURES IN INCREASING THE STUDENTS ABILITY AND INTEREST TO WRITE DESCRIPTIVE COMPOSITION. JOURNAL OF ADVANCED ENGLISH STUDIES, 2(1), 19-30.

Asrifan, A., Nadira, N., \& Haedar, H. (2018). IMPROVING STUDENTS'READING COMPREHENSION OF DESCRIPTIVE TEXT THROUGH COLLABORATIVE MURDER. JOURNAL OF ADVANCED ENGLISH STUDIES, 1(2), 21-31.

Asrifan, A. (2015). Analysis of English Students' Learning Style in Bilingual Class. International Journal of Literature and Arts, 3(4), 34.

Farahdiba, S., \& Asrifan, A. (2016). Speaking Ability and Psychological Barriers of the Second Year Students of Hotel Department of SMKN 1 Sidenreng Kabupaten Sidrap in Speaking English. Asian EFL Journal, (89), 41.

Asrifan, A. (2012). Increasing the Students Ability to Write Descriptive Composition at SMP Negeri 13 Parepare by using the 3-Dimension Pictures.

Tang, S., Asrifan, A., Chen, Y., Haedar, H., \& Agussalim, M. (2019). THE HUMOR STORY IN TEACHING READING COMPREHENSION. JOURNAL OF ADVANCED ENGLISH STUDIES, 2(2), 77-87.

Nurwanti, N., Asrifan, A., \& Haedar, H. (2019). THE APPLICATION OF COOPERATIVE LEARNING: JIGSAW II TECHNIQUE IN IMPROVING STUDENTS'READING COMPREHENSION OF EXPOSITORY TEXT. JOURNAL OF ADVANCED ENGLISH STUDIES, 2(1), 31-40.

Asrifan, A. (2016). The Effectiveness of Think-Pair-Share Technique in Improving Studentsâ€TM Speaking Ability and Interest. English Literature and Language Review, 2(3), 24-35.

Asrifan, A., Muthmainnah, M., Al-Yakin, A., Sahabuddin, C., \& Haedar, H. (2018). THE CAUSE-EFFECT TECHNIQUE IN TEACHING RECOUNT WRITING. JOURNAL OF ADVANCED ENGLISH STUDIES, 1(2), 63-72.

Asrifan, A., Vargheese, K. J., Syamsu, T., \& Amir, M. (2020). ESP COURSE DESIGN: THE NEED ANALYSIS ON TOURISM DEPARTMENT IN INDONESIA VOCATIONAL HIGH SCHOOLS. JOURNAL OF ADVANCED ENGLISH STUDIES, 3(2), 69-77.

Asrifan, A., Ghofur, A., \& Azizah, N. (2020). Cheating Behavior in EFL Classroom (A Case Study at Elementary School in Sidenreng Rappang Regency). OKARA: Jurnal Bahasa dan Sastra, 14(2), 279-297.

Nadirah, N., Asrifan, A., Vargheese, K. J., \& Haedar, H. (2020). INTERACTIVE MULTIMEDIA IN EFL CLASSROOM: A STUDY OF TEACHING READING COMPREHENSION AT JUNIOR HIGH SCHOOL IN INDONESIA. JOURNAL OF ADVANCED ENGLISH STUDIES, 3(2), 131-145.

Muthmainnah, A. R., Atmowardoyo, H., Salija, K., \& Asrifan, A. (2020). Literary Work as Teaching Materials: A Study of Students and Lecturers Needs Analysis. Solid State Technology, 63(5), 394-407.

Tilome, A. A., Agustang, A., Jasruddin, M. S., \& Asrifan, A. (2020). Social Exchange of Political Elites in the Regional Leader Election of Gorontalo Province, Indonesia. Solid State Technology, 63(5), 521-531.

Pacinongi, A., \& Asrifan, A. (2020). Bimbingan Pengawas Berkelanjutan dalam Mewujudkan Pendidikan Karakter Bangsa dalam Kegiatan Belajar Mengajar Penjaskes. Celebes Education Review, 2(1), 1-7.

Gunawan, G., \& Asrifan, A. (2020). Penerapan Kerja Kelompok Kegiatan MGMP Guru Ekonomi dalam Menyusun RPP untuk Meningkatkan Kompetensi Pedagogik. Celebes Education Review, 2(1), 31-36.

Yusuf, I., \& Asrifan, A. PENINGKATAN AKTIVITAS KOLABORASI PEMBELAJARAN FISIKA MELALUI PENDEKATAN STEM DENGAN PURWARUPA PADA SISWA KELAS XI IPA SMAN 5 YOGYAKARTA. Editorial Team, 32. 
Al Yakin, A., Sahabuddin, C., Rahayu, A., Fitrah, N., \& Arifin, M. (2020). Political Celebrification and Electability: A Study of Political Phenomena Imaging in Election Polewali Mandar District, West Sulawesi, Indonesia. Solid State Technology, 63(5), 632-646.

Junaedah, S. B. T., \& Ahmad, M. A. (2020). The Outdoor Learning Modules Based on Traditional Games in Improving Prosocial Behaviour of Early Childhood. International Education Studies, 13(10).

Octaberlina, L. R., \& Muslimin, A. I. (2020). Efl students perspective towards online learning barriers and alternatives using moodle/google classroom during covid-19 pandemic. International Journal of Higher Education, 9(6), 1-9.

Octaberlina, L. R., \& Anggarini, I. F. (2020). Teaching vocabulary through picture cards in Islamic Elementary School: a case study in Nida Suksa School, Thailand. Jurnal Madrasah, 13(1), 26-38.

Octaberlina, L. R. (2016). Plagiarism in English language theses in Indonesia. Jurnal Ilmu Pendidikan, 14(3).

Octaberlina, L. R., \& Anggarini, I. F. (2020). Teaching vocabulary through picture cards in Islamic Elementary School: a case study in Nida Suksa School, Thailand. Jurnal Madrasah, 13(1), 26-38.

Asrifan, A., Zita, C. T., Vargheese, K. J., Syamsu, T., \& Amir, M. (2020). THE EFFECTS OF CALL (COMPUTER ASSISTED LANGUAGE LEARNING) TOWARD THE STUDENTS'ENGLISH ACHIEVEMENT AND ATTITUDE. JOURNAL OF ADVANCED ENGLISH STUDIES, 3(2), 94-106.

Asrifan, A. (2021). ACADEMIC WRITING. LawArXiv. January, 2. https://doi.org/10.31228/osf.io/x2s7e

Asrifan, A. (2020). TUTORIAL PENGGUNAAN QUIZIZZ (www. quizizz. com) PADA PEMBELAJARAN. https://doi.org/10.31219/osf.io/kqnza

Asrifan, A. (2021). Abd Ghofur.“. THE USE OF READING CIRCLES IN INCREASING STUDENTS SPEAKING ABILITY AT THE ELEVENTH GRADE SMK NEGERI, 1. https://doi.org/10.31219/osf.io/8vjxy

Asrifan, A. (2020). Pandemic, Humanity and Education. https://doi.org/10.31219/osf.io/q2gpk

Asrifan, A. (2021). USING CAT AND MOUSE GAME TO IMPROVE STUDENT'S SPEAKING ABILITY AT THE ELEVENTH GRADE OF MA YMPI RAPPANG. https://doi.org/10.31219/osf.io/phtvn

Asrifan, A., \& Ghofur, A. (2021). THE USE OF READING CIRCLES IN INCREASING STUDENTS SPEAKING ABILITY AT THE ELEVENTH GRADE SMK NEGERI 1 PANCARIJANG. https://doi.org/10.31219/osf.io/8vjxy

Asrifan, A. (2021). Book Review: Halliday. 1989. Spoken and Written Language. Oxford University Press. https://doi.org/10.31219/osf.io/ej8tb

Asrifan, A., \& Ghofur, A. (2021). TALK, ACTION, SILENCE, INTERRUPTION AND THEIR IMPLICATIONS IN BUGINESE SOCIETY (SOPPENG https://doi.org/10.31219/osf.io/pv3ku

Asrifan, A. (2020). PENILAIAN BERBASIS ANDROID MENGGUNAKAN APLIKASI PLICKERS. https://doi.org/10.31219/osf.io/htreq

Haulussy, R. H., Najamuddin, I. R., \& Agustang, A. D. M. P. (2020). The sustainability of the Sasi Lola tradition and customary law (Case study in Masawoy Maluku, Indonesia). Intl J Sci Technol Res, 9(2), 5193-5195.

Arwan, A., Agustang, A., Arlin, A., Yani, A., \& PUTRA, D. M. (2019). Contestation of Elite Discourse in Treatment of HIV and AIDS. Iranian Journal of Public Health, 48(12), 2205.

Mutiara, I. A., Agustang, A., Adam, A., Upe, A., \& Equatora, M. A. (2020). The dynamics of prostitutes lives in metropolitan cities. Journal of Critical Reviews. https://doi. org/10.31838/jcr, 7, 165.

Usman, A., Agustang, A., Djalal, D., \& Annas, S. (2018, October). The Contribution Of Supporter Community In Maximizing Their Role For The Advancement Of Makassar Football Club (PSM). In 1st International 
Conference on Social Sciences (ICSS 2018). Atlantis Press.

Ma'na, P., Agustang, A., Salusu, J., Ikhsan, A., \& Dirawan, G. D. (2015). Decision making strategic value based local wisdom Tongkonan North Toraja. Man India, 95(3), 633-639.

Dirawan, G. D. FOSTERING COLLABORATION STREET CHILDREN IN MAKASSAR. Man In India, 95(3), 569-576.

Abdurachman, A. D. M. P. A., \& Agustang, A. Culture Of Shame-Heart And Social Solidarity Of Kaitetu People Central Maluku District, Indonesia.

Aida, K. N., Agustang, A., Arlin, A., \& Agustang, A. D. M. The Patron-Client Relationship Patterns In Siwa Lima Fishermen Community, Aru Islands District Maluku, Indonesia.

Pannyiwi, R., Agustang, A., Kasnawi, T., Pada, A. T., Yani, A., \& Syam, S. (2020). Social Network for Drug Circulation in Sidenreng Rappang Regency, Indonesia. Systematic Reviews in Pharmacy, 11(9), 575577.

Upe, A., Salman, D., \& Agustang, A. (2019). The effects of the exploitation of natural resources towards risk society construction in Southeast Sulawesi Province, Indonesia. Journal of Degraded and Mining Lands Management, 6(2), 1587.

Matakena, F., Watloly, A., Agustang, A., Adam, A., \& Alim, A. (2020). The Self-Concept of Ale Rasa Beta Rasa in the Orang Basudara Community in Ambon (Studies on the Community of Passo and Batumerah Country). International Journal, 9, 1307.

Asmi, A. S., Kasnawi, M. T., Agustang, A., \& Yani, A. (2020). Sociocultural Transformation in Efforts to Reduce Mortality of Infants in Bone Regency, Indonesia. Systematic Reviews in Pharmacy, 11(10), 762765.

Usmana, A., \& Agustangb, A. The Implementation of “Arif” Social Behaviour within Perssin Supporters in Sinjai District.

Hasan, I. R., Agustang, A., Kahar, F., \& Tahir, H. (2019). Super Service Delivery": an advanced conceptual model of one-stop service for wide administrative region. Problems and perspectives in management, (17, Iss. 1), 189-201.

Asrifan, A. (2021). ISSUES IN TEFL “International Article Summary \& Presentation”: Students' Reactions to School Based Oral Assessment: Bridging the Gap in Malaysia. https://doi.org/10.31228/osf.io/te3m5

Asrifan, A., Al Yakin, A., \& Sahabuddin, C. The Use of Dictogloss Technique on ELT Classroom: An Experiment Study of Students Listening Comprehension.

Octaberlina, L. R., \& Asrifan, A. (2021). THE USE OF HUMOR STORY IN IMPROVING THE STUDENTS'READING COMPREHENSION. https://doi.org/10.31219/osf.io/kvsbe

Octaberlina, L. R., \& Asrifan, A. (2021). THE TEXT-BASED CHARACTER IN TEACHING READING COMPREHENSION AT THE TENTH GRADE STUDENTS. https://doi.org/10.31219/osf.io/p53sn

Asrifan, A. (2021). CODE MIXING AND CODE SWITCHING IN THE EFL CLASSROOM INTERACTION. https://doi.org/10.31228/osf.io/xd45c

Asrifan, A. (2021). ADVANCED GRAMMAR “Adverbs and Adverb Clauses". https://doi.org/10.31228/osf.io/cuh83

Asrifan, A. (2020). TUTORIAL PENGGUNAAN QUIZIZZ (www. quizizz. com) PADA PEMBELAJARAN. https://doi.org/10.31219/osf.io/kqnza

Asrifan, A., \& Aeni, N. Book Review: I SPEAK FIVE LANGUAGES: FOSTERING PLURILINGUAL COMPETENCE THROUGH LANGUAGE AWARENESS By: Oliveira and Helena, Maria. https://doi.org/10.31228/osf.io/tjnq9

Asrifan, A. (2021). Modul Perkuliahan RESEARCH ON ENGLISH LANGUAGE TEACHING. 
https://doi.org/10.31219/osf.io/5rgvc

Asrifan, A. (2021). IMPROVING STUDENTS'SPEAKING ABILITY BY USING HAND DOLLS OF THE ELEVENTH GRADE STUDENTS OF MA YMPI RAPPANG. https://doi.org/10.31219/osf.io/zfhqu

Asrifan, A., Octaberlina, L. R., \& Handayani, R. (2021). SEMANTIC ANALYSIS ON THE USE OF ENGLISH LANGUAGE SLOGAN. https://doi.org/10.35542/osf.io/vtx5y

Asrifan, A. (2021). Book Review KONSTRUKSI GROUNDED TEORI Petunjuk Praktis Dalam Analisa Kualitatif Written By: Kathy Charmez. https://doi.org/10.31228/osf.io/nt8yk

Qisti, N., Nurwidah, A., Muslimin, I., \& Asrifan, A. (2020). THE EFFECT OF TEMPERATURE AND TIME DRYING TOWARD ORGANOLEPTIC QUALITY OF THE DUCKS BONE MEAL. Solid State Technology, 63(6), 19652-19659.

Asrifan, A., \& Ghofur, A. Book Review: Writing for Academic Journals Second Edition. https://doi.org/10.31219/osf.io/su3ya

Andi Asrifan, N. (2020). THE TEXT-BASED CHARACTER IN TEACHING READING COMPREHENSION AT THE TENTH GRADE STUDENTS OF SMAN 4 SENRENG RAPPANG. Sarwah: Journal of Islamic Civilization and Thought, 18(02), 33-51.

Octaberlina, L. R., \& Asrifan, A. (2021). THE USE OF HUMOR STORY IN IMPROVING THE STUDENTS'READING COMPREHENSION.

Agustang, A., Mutiara, I. A., \& Asrifan, A. (2021). Genealogi Stigma Sosial Terhadap Pasien Covid 19. https://doi.org/10.31219/osf.io/ep7jf

Agustang, A., Ahriani, A., \& Asrifan, A. (2021). MARGINALISASI BUDAYA (STUDI PADA PRANATA SOSIAL MASYARAKAT MUSLIM SUKU KOKODA KOTA SORONG). https://doi.org/10.31219/osf.io/942y8

Agustang, A., Ariani, A. I., \& Asrifan, A. (2021). KONSTRUKSI SOSIAL JANDA TEREKSPLOITASI (STUDI KASUS DI KELURAHAN TETEBATU KECAMATAN PALLANGGA KABUPATEN GOWA).

Asrifan, A. (2021). APLIKASI DAN IMPLIKASI BERPIKIR SISTEMIK (SYSTEMIC THINKING) DALAM KEHIDUPAN.

Asrifan, A. (2021). PSIKOLOGI BELAJAR/TEORI BELAJAR: IMPLIKASI DAN HARAPAN.

Asrifan, A. (2021). PENDALAMAN MATA KULIAH SOCIOLINGUISTICS VARIASI SOSIAL PENGGUNA BAHASA.

Agustang, A. (2021). INTERAKSI SOSIAL KOMUNITAS LOKAL DENGAN PENDATANG DAN PERUBAHAN STRUKTUR KOMUNITAS LOKAL (Studi pada Masyarakat Majemuk di Kawasan Industri Makassar).

Agustang, A. (2021). KESEJAHTERAAN PSIKOLOGIS (studi Pada Dewasa Madya Yang Belum Menikah Di Kota Makassar). 